\title{
HIV-1 Vpu and HIV-2 Env counteract BST-2/ tetherin by sequestration in a perinuclear compartment
}

\author{
Heiko Hauser ${ }^{1}$, Lisa A Lopez' ${ }^{1}$ Su Jung Yang ${ }^{1}$, Jill E Oldenburg ${ }^{1}$, Colin M Exline', John C Guatelli ${ }^{2}$ and \\ Paula M Cannon ${ }^{1 *}$
}

\section{Correction}

A confocal image in Figure 3B of Hauser et al. 2010 [1], showing TGN staining of Vphu-HcRed expressing cells (middle row,) was incorrect. This image has now been replaced with the correct image.

\section{Additional material}

Additional file 1: Updated versions of Figure 3 of Hauser et al. 2010 [1]. Redistribution of tetherin to an intracellular compartment by HIV antitetherin factors. (A) The percentage of HeLa cells displaying tetherin concentrated in a perinuclear compartment (PNC) was calculated for 100 cells, from either control (Ctrl.) cells or cells transfected with $2 \mu \mathrm{g}$ of Vpu or ROD10 Env expression plasmids. Mean +/- SEM is shown for $n=2$ independent experiments. (B) HeLa cells transfected with either Vpu (Vphu-HcRed) or ROD10 Env, showed increased concentration of tetherin in a perinuclear compartment (arrowed), that co-stained with the TGN marker, TGN46. The triple color merged image is shown. Scale bars represent $10 \mu \mathrm{M}$

\section{Author details}

${ }^{1}$ Keck School of Medicine of the University of Southern California, California Los Angeles, CA 90089, USA. ${ }^{2}$ University of California San Diego, 9500 Gilman Dr., La Jolla, CA 92093, California, USA.

Received: 20 October 2011 Accepted: 25 October 2011

Published: 25 October 2011

\section{Reference}

1. Hauser Heiko, Lopez ALisa, Yang JSu, Oldenburg EJill, Exline MColin,

Guatelli CJohn, Cannon MPaula: HIV-1 Vpu and HIV-2 Env counteract BST2/tetherin by sequestration in a perinuclear compartment. Retrovirology 2010, 7:51

doi:10.1186/1742-4690-8-85

Cite this article as: Hauser et al.: HIV-1 Vpu and HIV-2 Env counteract BST-2/tetherin by sequestration in a perinuclear compartment. Retrovirology 2011 8:85.

\footnotetext{
* Correspondence: pcannon@usc.edu

${ }^{1}$ Keck School of Medicine of the University of Southern California, California Los Angeles, CA 90089, USA
}

Full list of author information is available at the end of the article

Submit your next manuscript to BioMed Central and take full advantage of:

- Convenient online submission

- Thorough peer review

- No space constraints or color figure charges

- Immediate publication on acceptance

- Inclusion in PubMed, CAS, Scopus and Google Scholar

- Research which is freely available for redistribution

Submit your manuscript at www.biomedcentral.com/submit
() Biomed Central 